QUALITY

Volume 8, Nomor 2, 2020, 241-268

\title{
SUPERVISI AKADEMIK KEPALA MADRASAH DALAM MENINGKATKAN KOMPETENSI PROFESIONAL GURU (STUDI MULTI KASUS MADRASAH ALIYAH NEGERI KABUPATEN PATI)
}

\author{
Faizatun \\ Kantor Kemenag Kabupaten Pati, Indonesia \\ faizatunkarim@gmail.com \\ Fathul Mufid \\ IAIN Kudus \\ fathul.mufid@gmail.com
}

\begin{abstract}
Abstrak
Penelitian ini dilatarbelakangi kurang optimalnya kegiatan Kepala Madrasah dalam mensupervisi guru. Penelitian ini bertujuan untuk menjawab permasalahan: (1) bagaimana pelaksanaan supervisi akademik oleh Kepala Madrasah, (2) bagaimana faktor pendukung kegiatan Supervisi Akademik dan hambatannya, serta (3) bagaimana peran Kepala Madrasah sebagai supervisor. Penelitian ini mengikuti model studi multi kasus, dengan pendekatan kualitatif deskriptif. Berlokasi di MAN 1 Pati dan MAN 2 Pati. Hasil penelitian menunjukkan: (1) pelaksanaan Supervisi Akademik meliputi tiga kegiatan, yaitu perencanaan program (b) strategi Supervisi Akademik, (c) evaluasi menggunakan instrumen penilaian baku mengacu aturan Kementerian Agama, dengan tindak lanjut memberikan penguatan dan penghargaan serta pembinaan dan pelatihan. (2) Faktor-faktor pendukung meliputi jadwal supervisi akademik, kesediaan guru disupervisi, sikap guru senior yang kooperatif, kelengkapan administrasi pembelajaran, kontinyuitas pelaksanakan Supervisi Akademik. Faktor-faktor penghambat terdiri dari keterbatasan waktu Kepala Madrasah dan guru, beban guru mengajar yang tidak sesuai dengan latar belakang Pendidikan (3) Peran Kepala Madrasah sebagai Supervisor memiliki kompetensi: merencanakan program, melaksanakan dan melakukan evaluasi serta menindaklanjuti hasil Supervisi Akademik.
\end{abstract}

Kata kunci: Supervisi Akademik, Kepala Madrasah, Kompetensi Professional Guru 


\begin{abstract}
This research is motivated by the less optimal activities of the Madrasah Head in supervising teachers. This study aims to answer the problem:(1) how the implementation of academic supervision by the Head of Madrasa (2) how the factors supporting Academic Supervision activities and their obstacles, and (3) how the role of the Madrasah Head as a supervisor. This research follows a multi-case study model, with a descriptive qualitative approach. Located in MAN 1 Pati and MAN 2 Pati. The results showed: (1) Implementation of Academic Supervision includes three activities, namely: (a) program planning, (b) Academic Supervision strategy, and (c) evaluation using standard assessment instruments referring to the rules of the Ministry of Religion, with follow-up giving reinforcement and appreciation as well as coaching and training. (2) Supporting factors include the schedule of academic supervision, the willingness of supervised teachers, fellow teaching professions, the attitude of the cooperative senior teachers, completeness of the administration of learning, continuity of the Madrasah Head in carrying out Academic Supervision. The inhibiting factors consist of the limited time of the Madrasah Head and the teacher, the burden of the teacher teaching that is not following the educational background. (3) The Role of the Madrasah Head as a Supervisor has competence: planning programs, implementing and evaluating, and following up on Academic Supervision results. Implementation of Academic Supervision includes three activities, namely: (a) program planning, (b) Academic Supervision strategy by setting targets focused (c) evaluation using standard assessment instruments. (2) Supporting factors. (3) The Role of the Madrasah Head as a Supervisor has competence.
\end{abstract}

Keywords: Academic Supervision, Principal of Madrasa, Teacher Professional Competence

\title{
A. Pendahuluan
}

Pelaksanaan supervisi akademik oleh kepala madrasah menjadi tolok ukur terhadap perkembangan dan peningkatan mutu guru dan kualitas proses pembelajaran yang berpengaruh terhadap capaian mutu lulusan, Realitas menunjukkan kegiatan supervisi akademik pelaksanaan kurang optimal dijalankan kepala madrasah. Hasil penilaian kinerja kepala madrasah oleh pengawas madrasah menunjukkan : (1) Kepala madrasah melaksanakan kegiatan supervisi akademik belum makasimal; (2) Masih banyak guru belum memahami tujuan supervisi 


\section{Faizatun dan Fathul Mufid}

akademik; (3) Pengelolaan supervisi akademik belum terprogram secara sistematis; (4) Program supervisi akademik belum semua terlaksana; dan (5) Belum semua guru memperoleh tindak lanjut dari hasil supervisi akademik yang dilakukan oleh kepala madrasah

Peran kepala madrasah sebagai supervisor bertanggung jawab meningkatkan kemampuan guru dalam mengelola kegiatan belajar mengajar dan berperan penting terhadap prningkatan mutu madrasahnya. Hal ini, mengharuskan Kepala Madrasah melakukan kegiatan supervisi dengan benar dan berpegang pada prinsip-prinsip supervisi, teknik dan pendekatan supervisi yang tepat sehingga mampu meningkatkan kompetensi professional guru, yang berdampak signifikan pada peningkatkan kualitas mutu lulusan, dengan cara memfasilitasi guru untuk selalu memutahirkan kompetensi yang dimilikinya, guru melakukan pengembangan profesi secara aktif untuk meningkatkan pengetahuan, ketrampilan dan wawasan sehingga mampu meningkatkan pelaksanaan kegiatan proses pembelajaran yang lebih aktif, kreatif, inovatif serta professional. yang dapat dilakukan seperti diforum MGMP.

Realita menunjukkan pelaksanaan MGMP di lingkup madrasah belum optimal, Sebagian guru memiliki beban mengajar yang tinggi, guru mengajar tidak sesuai dengan latar belakang keilmuannya, bahkan hasil pendampingan, observasi dan verifikasi pelaksanaan Penilaian Kinerja Guru (PKG) oleh kepala madrasah yang diwakili Wakabid Kesiswaan di Madrasah Aliyah Negeri 1 Pati ditemukan permasalahan antara lain : Kebanyakan guru belum menyajikan materi secara kontekstual dan cenderung tekstual, pelaksanaan proses pembelajaran yang dilaksanakan guru masih mengedepankan aspek kognisi daripada afeksi dan psikomotorik, banyaknya guru yang belum memanfaatkan media pembelajaran berbasis ICT.

Berpijak pada paparan tersebut, peneliti bermaksud untuk melakukan penelitian berjudul "Supervisi Akademik Kepala Madrasah Dalam Meningkatkan Kompetensi Profesional Guru (Studi Multi Kasus Madrasah Aliyah Negeri 
Kabupaten Pati)". Dalam hal ini dirumuskan permasalahan penelitian berikut ini: Bagaimana pelaksanaan supervisi akademik dalam meningkatkan kompetensi provesional guru di MAN Pati; Apa faktor-faktor pendukung dan penghambat dalam melaksanakan supervisi akademik bagikepala madrasah untuk meningkatkan kompetensi provisional guru di MAN Pati? Serta Bagaimana peran Kepala Madrasah sebagai supervisor dalam meningkatkan kompetensi profesional guru di MAN Pati; dengan tujuan mendeskripsikan pelaksanaan supervisi akademik dan menjelaskan factor pendukung dan penghambat dalam pelaksanaan supervise akademik serta menjelaskan peran kepala madrasah sebagai supervisor dalam melaksanakan supervise akademik di MAN Pati.

Penelitian ini berjenis studi multi kasus yakni penelitian yang dilakukan lebih dari satu tempat. Penelitian ini berlokasi di MAN 1 Pati dan MAN 2 Pati Subjek Penelitian Kepala Madrasah MAN 1 dan MAN 2 Pati. Pada Penelitian ini, dilakukan wawancara dengan Kepala Madrasah, Wakil kepala madrasah dan guruguru yang mengajar di MAN 1 Pati dan MAN 2 Pati. Alasan pemilihan lokasi dilatarbelakangi oleh Madrasah tersebut memiliki karakteristik yang berbeda dimana situasi dan kondisi daerah tempat sekolah tersebut berada, dan kondisi obyektif sekolah. Satu sisi berada ditengah kota memiliki rintisan boarding school dan sisi lain berada di ujung utara kota Pati, kedua madrasah memiliki prestasi akademik dan non akademk., Madrasah diminati masyarakat dengan jumlah siswa diatas 900, banyak peserta didik yang berasal dari luar daerah, Madrasah tersebut mudah dijangkau dengan tranportasi yang strategis. Teknik pengumpulan data melalui observasi, wawancara dan dokumentasi. Pengujian keabsahan data melalui kredibilitas, transferabilitas, dependabilitas, konfirmabilitas. Proses analisis data mencakup : (1) Pengumpulan Data (Data Collection) (2) Reduksi data (Data Reduction (3) Penyajian Data (Data Display), (4) Verifikasi (Conclusion Drawing).

\section{B. Pembahasan}

\section{Supervisi Akademik}




\section{Faizatun dan Fathul Mufid}

Supervisi secara etimologis, berasal dari bahasa Inggris supervision yang berarti pengawasan (KBBI, 2009). Kata ini berasal dari dua kata super dan vision yang berarti melihat dengan teliti pekerjaan secara keseluruhan (Masaong, 2012). Supervisi akademik merupakan layanan profesional berbentuk pemberian bantuan kepada personil sekolah yaitu guru dalam meningkatkan kemampuannya untuk lebih mampu mempertahankan dan melakukan perubahan penyelenggaraan sekolah dalam meningkatkan pencapaian tujuan sekolah (Maunah,2009). Supervise akademik di madrasah sacara implementatif dilaksanakan oleh kepala madrasah atau guru yang ditugaskan oleh kepala madrasah selaku penanggungjawab mutu madrasah. Oleh karena itu pembinaan dan pembimbingan profesional terhadap guru-guru supaya berkembang dalam melaksanakan tugas pokoknya perlu dilakukan supervisi akademik.

Menurut Glickman mendefinisikan "Academic supervision is a series of activities helping teachers develop their ability to manage the learning prosess for the achievement of learning objectives" (Glickman, Gordon 2009). Pendapat tersebut menjelaskan bahwa supervisi akademik adalah serangkaian kegiatan untuk membantu guru mengembangkan kemampuan mengelola proses pembelajaran demi pencapaian tujuan pembelajaran. Supervisi Akademik diartikan sebagai kegiatan pengawasan, difokuskan pada aspek pembinaan dan pembimbingan professional dalam peningkatan kompetensi profesional guru yang bermuara pada peningkatan mutu pedndidikan.

Prinsip-prinsip supervisi akademik modern menurut pendapat Tahalele dan Indrafachrudi dalam Supi Pauzi, yaitu (Pauzi, 2012) : (1) Supervisi akademik harus mampu menciptakan hubungan kemanusiaan yang harmonis, bersifat terbuka, kesetiakawanan, dan informal, (2) Supervisi akademik harus dilakukan secara berkesinambungan, (3) Supervisi akademik harus demokratis, (4) Program supervisi akademik harus integral dengan program pendidikan secara keseluruhan, (5) Supervisi akademik harus komprehensif, (6) Supervisi akademik harus konstruktif. Sedangkan Prinsip-prinsip khusus Supervisi Akademik Kepala 


\section{Faizatun dan Fathul Mufid}

Madrasah, mencakup : (1) praktis), (2) sistematis (3) objektif (4) realistis (5) antisipatif (6) konstruktif (7) kooperatif (8) kekeluargaan (9) demokratis (10) aktif (11) Humanis (mampu menciptakan hubungan kemanusiaan yang harmonis, terbuka, jujur, sabar, antusias dan penuh humor), (12) berkesinambungan (supervisi dilakukan secara teratur dan berkelanjutan), (13) terpadu (menyatu dengan program pendidikan), dan (14) komprehensif . (Kemenag,2019).

Implementasi supervisi akademik oleh kepala madrasah meliputi : (1) Perencanaan program supervisi akademik, yaitu : (a) Peningkatan pemahaman guru terhadap Kurikulum 2013 dititikberatkan, pada : Review Kurikulum 2013 (pengembangan Silabus), perumusan KD dan IPK, Penyusunan RPP, (b) Penggunaan metode-metode dan model-model pembelajaran yang lebih variatif dan meningkatkan antusiasme peserta didik dalam proses pembelajaran, (c) pelaksanaan proses pembelajaran yang efektif dan efisien dengan mengacu kepada tuntutan penguasaan kompetensi, (d) penggunaan instrumen penilaian yang sesuai dengan tuntutan kompetensi, dan (e) penggunaan media pembelajaran. (2) pelaksanaan supervisi akademik dengan teknik individual dan kelompok (Prasoko, 2011).

Teknik individual meliputi: kunjungan kelas, observasi kelas, pertemuan individual, kunjungan antar kelas, dan menilai diri sendiri. Teknik supervisi akademik berkelompok meliputi : mengadakan pertemuan atau rapat (meeting), Studi kelompok antar guru mata pelajaran sejenis (MGMP), Workshop, Demonstrasi, Mengadakan penataran-penataran (inservice-training), mengadakan diskusi kelompok (group discussions), Seminar, dan Pertemuan ilmiah. (3) Evaluasi supervisi akademik terhadap guru perlu dilakukan agar dapat diketahui apakah supervisi akademik yang dilakukan telah dapat mencapai target yang ditentukan. (4) Tindak lanjut supervisi akademik terhadap guru berupa penguatan dan penghargaan diberikan kepada guru yang telah memenuhi standar, teguran yang bersifat mendidik diberikan kepada guru yang belum memenuhi standar dan guru diberi kesempatan untuk mengikuti pelatihan /penataran lebih lanjut. 


\section{Faizatun dan Fathul Mufid}

Kata Kepala Sekolah berasal dari dua kata yaitu, kepala dan sekolah. Kata kepala dapat diartikan "ketua" atau pemimpin dalam suatu organisasi atau suatu lembaga. Sedangkan sekolah adalah sebuah lembaga pendidikan dimana menjadi tempat menerima dan memberi pelajaran (KBBI, 1988). Secara sederhana kepala sekolah dapat didefinisikan sebagai "seorang tenaga fungsional guru yang diberi tugas untuk memimpin suatu madrasah dimana diselenggarakan proses belajar mengajar atau tempat dimana terjadi interaksi antara guru yang memberi pelajaran dan murid yang menerima pelajaran (Wahjosumidjo, 2007). Dari definisi tersebut dapat disimpulkan bahwa kepala sekolah merupakan pimpinan tertinggi dalam lembaga pendidikan yang bertanggung jawab terhadap segala sesuatu yang berhubungan dengan kelancaran jalannya sekolah demi terwujudnya tujuan sekolah tersebut.

Persyaratan Kepala Madrasah diatur pada Permendiknas R.I. Nomor 13 Tahun 2007, tentang Standar KepalaSekolah/Madrasah, bahwa "Kepala Madrasah harus memiliki standar kompetensi : (1) kompetensi kepribadian, (2) kompetensi manajerial, (3) kompetensi kewirausahaan, (4) kompetensi supervisi dan (5) kompetensi social (Yunandra, 2019). Salah satu kompetensi yang dimiliki oleh kepala sekolah adalah kompetensi supervisi yaitu : (1) Merencanakan program supervisi akademik dalam rangka peningkatan profesionalisme guru, (2) Melaksanakan supervisi akademik terhadap guru dengan menggunakan pendekatan dan teknik supervisi yang tepat, dan (3) Menindaklanjuti hasil supervisi akademik terhadap guru dalam rangka peningkatan profesionalisme guru. Strategi kepala sekolah dalam meningkatkan profesionalisme guru, melalui pembinaan disiplin tenaga kependidikan, pemberian motivasi, penghargaan (reward) dan persepsi (Mulyasa, 2010).

Peran Kepala Madrasah sebagai supervisor memiliki tanggung jawab untuk membina, membimbing, melatih, memantau, dan memperbaiki proses pembelajaran. Tanggung jawab ini dikategorikan sebagai tanggung jawab supervisi. Fungsi Supervisi Akademik adalah upaya pendampingan yang bersifat konsultatif 


\section{Faizatun dan Fathul Mufid}

dalam rangka mewujudkan perbaikan berkelanjutan dan peningkatan kualitas proses pembelajaran di madrasah. Kepala madrasah harus mampu membantu seluruh warga madrasah mewujudkan tujuan pembelajaran yaitu membantu perkembangan individu para siswa memiliki kompetensi dan karakter sesuai dengan tujuan pendidikan, melalui proses pembelajaran yang berkualitas, inovatif dan menyenangkan

Undang-Undang Nomor 14 Tahun 2005 tentang Guru dan Dosen Pasal 1 ayat 4 menyatakan "profesional adalah pekerjaan atau kegiatan yang dilakukan oleh seseorang dan menjadi sumber penghasilan kehidupan yang memerlukan keahlian, kemahiran, atau kecakapan memenuhi standar mutu atau norma tertentu serta memerlukan pendidikan profesi". Petersalim dalam kamus bahasa Indonesia Kontemporer mengartikan guru adalah orang yang pekerjaannya mendidik, mengajar, dan mengasihi, sehingga seorang guru harus bersifat mendidik (Salim and Salim, 1993). Ahmad D. Marimba, menyatakan "guru adalah orang yang mempunyai tanggung jawab untuk mendidik" (Marimba, 1989). Amien Daiem Indrakusuma menyatakan "guru adalah pihak atau subyek yang melakukan pekerjaan mendidik" (Indrakusuma, 1993).

Seorang guru sebagai pengelola proses pembelajaran dituntut memiliki kompetensi profesional, maka guru harus memiliki kemampuan : (1) Merencanakan pembelajaran mencakup : Merumuskan tujuan, Memilih prioritas materi yang akan diajarkan, Memilih dan menggunakan metode, sumber belajar, dan media pembelajaran, (2) Melaksanakan sistem pembelajaran, meliputi : Memilih bentuk pembelajaran yang tepat dan Menyajikan urutan pembelajaran secara tepat, (3) Mengevaluasi sistem pembelajaran, meliputi : Memilih dan menyusun jenis evaluasi, Melaksanakan kegiatan evaluasi sepanjang proses pembelajaran berlangsung, dan Mengadministrasikan hasil evaluasi, (4) Mengembangkan sistem pembelajaran, meliputi : Mengoptimalisasikan peserta didik, Meningkatkan wawasan kemampuan diri sendiri, dan Mengembangkan program pembelajaran lebih lanjut (Hamzah, 2011). 


\section{Pelaksanaan Supervisi Akademik}

Hasil wawancara dengan kepala madrasah Moh Kodri S.Pd mengatakan Pelaksanaan Supervisi Akademik di MAN 1 Pati, dipaparkan sebagai berikut: Program perencanaan Supervisi Akademik disusun secara kolaboratif yatiu melibatkan seluruh elemen MAN 1 Pati, bertujuan untuk memperbaiki beberapa aspek yang belum tuntas pada supervisi tahun sebelumnya. Perencanaan superfisi akademik oleh Kepala Madrasah diawali dengan penyusunan program supervisi akademik berupa Program Tahunan (Prota) dan Program Semester (Promes ) yang dialkukan pada setiap awal tahun pelajaran baru, mulai pertengahan bulan Juni sampai bulan Juli tahun pelajaran yang akan dating melalui rapat koordinasi madrasah (kepala, Waka, guru inti dan Kapala bagian administrasi). Perencanaan dilaksanakan secara berkesinambungan, bertujuan menstimulasi motivasi guru untuk meningkatkan kompetensinya. Penyusunan Prota dan Promes, merencanakan pembinaan guru dengan dilengkapi instrumen pendukung, diantaranya: (1)Instrumen Supervisi RPP, (2) Instrumen Supervisi Proses Pembelajaran (K13), dan (3) Instrumen Supervisi Penilaian Proses dan Hasil Belajar siswa.

Wawancara dengan Bambang Budiono guru Bhs Inggris di MAN 1 Pati menyebutkan ada empat aspek yang dipersiapkan kepala madrasah dalam menyusun perencanaan program Supervisi Akademik, yaitu : (1) menetapkan tujuan yang ingin dicapai, yaitu : meningkatkan kompetensi profesional guru, (2) Fokus pada sasaran yang ingin ditingkatkan yaitu : kinerja mengajar, (3) menyusun strategi Supervisi Akademik, meliputi : (a) perlengkapan sarpras yang mendukung kegiatan supervisi akademik, (b)menetapkan guru yang akan disupervisi, (c) prosedur/strategi pelaksanaan Supervisi Akademik, dan (d) menginformasikan perencanaan program supervisi kepada guru, dan (4) menyusun jaduwal Supervisi Akademik. Selanjutnya keempat aspek tersebut dibuat dalam bentuk dokumen perencanaan program. Selain itu, hasil wawancara dengan Jaja T. guru Biologi di MAN 1 Pati menyatakan tentang aspek-aspek yang dipersiapkan guru dalam 


\section{Faizatun dan Fathul Mufid}

membantu Kepala Madrasah menyusun perencanaan Supervisi Akademik dengan mempersiapkan administrasi pembelajaran, meliputi: (1) Kalender Pendidikan; (2) Program tahunan, (3)Program semester, (4) Silabus, (5) RPP, (6) Jadwal tatap Muka, (7) Agenda Harian, (8) Daftar Nilai (Sikap, Pengetahuan, keterampilan), (9) KKM, (10) Absensi Peserta didik, (11) Buku Pegangan Guru, dan (12) Buku Teks Peserta didik.

Pelaksanaan supervisi akademik oleh bapak Moh. Kodri kepala MAN 1 agar berjalan eefektif pelaksanaan dilakukan secara terjaduwal satu tahun dua kali yaitu pada semester gasal dan genap. Didalam pelaksanaan supervisi, dilakukan pembinaan dan pendampingan terhadap guru yang disupervisi untuk menyiapkan perangkat pembelajaran. Kepala Madrasah dituntut memiliki kemampuan dan ketrampilan untuk menyusun strategi dengan memperhatikan prinsip-prinsip dalam melaksanakan supervisi, diantaranya : humanis (mampu menciptakan hubungan kemanusiaan yang harmonis, terbuka, jujur dan antusias), berkesinambungan (supervisi dilaksanakan secara teratur dan berkelanjutan), transparan, demokratis (supervisor tidak boleh mendominasi dalam kegiatan supervise), komprehensif (memenuhi ketiga tujuan supervisi), konstruktif (mampu mengembangkan kreatifitas dan inovasi guru dalam proses pembelajaran), obyektif, dan ilmiah. Teknik supervise akademik yang digunakan untuk meningkatkan kompetensi profesional guru adalah: teknik individual dan teknik berkelompok.

Pelaksanaan supervisis teknik individual ditujukan kepada guru tertentu yang memiliki permasalahan khusus dalam melaksanakan pembelajaran. Bentuk pelaksanaan supervise individual adalah supervisi kunjungan kelas, observasi kelas, pertemuan individu dan kunjunganan antar kelas. Kepala Madrasah sering melakukan control di pagi hari dengan memantau proses pembelajaran di tiap-tiap kelas. Supervisi kunjungan antar kelas juga dilaksanakanya itu dengan menugaskan atau inisiatif sendiria ntar guru untuk saling berkunjung kekelas lain untuk berbagi pengalaman dalam pembeljaran. Aktivitas Kepala Madrasah dalam melaksanakan supervisi antar kelas dengan memberikan arahan kepada guru yang mengalami 


\section{Faizatun dan Fathul Mufid}

kesulitan untuk melaksanakan penelitian tindakan kelas (PTK), maka disarankan untuk berkolaborasi antar guru.

Pelaksanaan supervisi teknik kelompok, dengan mengelompokkan para guru yang dinilai kinerjanya kurang maksimal, dan memiliki masalah yang sama. Teknik supervisi kelompok yang dilakukan oleh Kepala Madrasah, meliputi: Pertemuan rapat guru (meeting), diskusi kelompok, penataran, demonstrasi, pertemuan ilmiah dan Workshop. Kegiatan tersebut dijabarkan sebagai berikut: Pertemuan Rapat (Meeting).

Evaluasi pelaksanaan supervise akademik Kepala Madrasah menggunakan instrumen standar proses kegiatan pembelajaran yang telah ditetapkan. Alat yang digunakan adalah instrumen penilaian kompetensi profesional guru yang telah dibuat pada program perencanaan. Penilaian guru didasarkan pada alat evaluasi berupa: instrumen perencanaan pembelajaran, instrumen pelaksanaan pembelajaran dan instrumen penilaian proses dan hasil belajar siswa, Pelaksanaan evaluasi ditujukan pada semua program yang telah disusun oleh Kepala Madrasah.

Evaluasi difokuskan pada kompetensi profesional, dijabarkan sebagai berikut: (a) Kemampuan guru menyusun perencanaan pembelajaran,. (b) Kemampuan guru melaksanakan proses pembelajaran brtbasis Kurikulum 2013, (c) Kemampuan guru mengadakan evaluasi pembelajaran meliputi : (penilaian harian, penilaian tengah semester, penilaian akhir semester dan penilaian ahir tahun, baik penilaian pengetahuan (kognitif), penilaian keterampilan (psikomotorik), dan penilaian sikap (afekti), kemampuan guru melaksanakan remidial dan pengayaan, kemampuan guru menganalisis ulangan harian, penilaian tengah semester (PTS), Penilaian Ahir semester (PAS) dan penilaian ahir tahun (PAT) dan penyusunan Bank Soal. Kriteria penilaian menggunakan sistem skor dengan kriteria Amat Baik, (A) juka diperoleh nilai antara 86 s.d.100; Kriteria Baik (B) jika diperoleh nilai antara 70 s.d. 85, Kriteria Kurang (C), nilainya di bawah 70, ketentuan tersebut telah ditetapkan dalam pedoman supervise oleh Kementerian Agama. 


\section{Faizatun dan Fathul Mufid}

Kepala Madrasah dalam melaksanakan kegiatan tindak lanjut dengan langkah-langkah: (a) Mengadakan pertemuan individual, dengan cara memanggil guru yang disupervisi setelah pembelajaran berakhir. (b) Pelaksanaan pembinaan secara berkelompok dengan guru mata pelajaran yang serumpun (MGMP) baik ditingkat satuan Pendidikan maupun MGMP tingkat kabupaten, pembinaan dilakukan dengan menyesuaikan kegiatan guru dan mengikutkan guru dalam kegiatan pengembangan keprofesian berkelanjutan atas undangan instansi terkait.

Faktor pendukung yang menjadikan pelaksanaan supervise akademik berjalan dengan baik adalah: (1) adanya sosialisasi jadwal Supervisi Akademik, (2) Kesediaan guru untuk disupervisi, (3) Administrasi guru yang lengkap, (4) Kepala Madrasah melaksanakan supervisi secara berkesinambungan dan berkelanjutan kepada semua guru, (5) kesediannya guru senior diajak kolaborasi untuk membimbing teman sejawat, (6) kondisi peserta didik yang tertib saat berlangsungnya kegiatan supervisi akademik baik dengan teknik kunjungan kelas maupun teknik observasi kelas, dan (7) Guru yang mau bekerjasama dan kualifikasi guru yang sesuai dengan standar. Sedangkan factor penghambatnya adalah (1) kurangnya persiapan Guru untuk disupervisi; (2) Administrasi guru kurang lengkap terutama Program Semester, Rencana Pelaksanaan Pembelajaran (RPP); (3) Perbedaaan latar belakang pendidikan, (4) rendahnya kesadaran akan pemahaman pentingnya supervisi akademik Kepala Madrasah dan guru (5) Kesibukan kepala madrasah dengan tugas kedinasan yang kadang bersamaan.

Informasi yang diperoleh hasil wawancara dengan kepala madrasah bpk. Amirudin aziz beserta wakakur menuturkan bahwa Penyusunan perencanaan program Supervisi Akademik merupakan salah satu peran dan tugas Kepala Madrasah. Bentuk kegiatan Supervisi Akademik berupa pembinaan,pembimbingan dan pemantauan, melaksanakan tindak lanjut serta memperbaiki pelaksanaan pembelajaran di kelas ataupun di luar kelas. Adapun sasarannya adalah seluruh guru terutama guru pemula. Penyusunan perencanaan program Supervisi Akademik yang dilaksanakan di MAN 2 Pati, disusun secara sistematis dan dilaksanakan awal 


\section{Faizatun dan Fathul Mufid}

semester gasal dan awal semester genap, dengan menyiapkan instrumen Supervisi Akademik yang diatur dalam peraturan perundangan oleh Kementerian Agama.

Kegiatan Supervisi Akademik dilaksanakan Kepala Madrasah secara konsisten, berkelanjutan dan terpadu antara program supervisi dan program pendidikan. Kepala Madrasah menggunakan empat prinsip dalam melaksanakan Supervisi Akademik di MAN 2 Pati yaitu : (1) Prinsip ilmiah (scientific), berdasarkan data objektif dan dilaksanakan secara sistematis, berencana dan kontinyu, (2) Prinsip demokratis dengan menjunjung tinggi harga diri dan martabat guru, (3) Prinsip kerja sama, dikembangkan usaha bersama saling memberi support, mendorong, menstimulasi guru, dan (4) Prinsip konstruktif dan kreatif, menolong guru-guru agar memiliki keyakinan, optimis, dan mandiri. Kepala Madrasah melaksanakan Supervisi Akademik melalui kunjungan kelas (Kepala Madrasah datang ke kelas untuk mengobservasi guru mengajar), observasi kelas (guru ditugaskan untuk mengamati rekan guru lainnya yang sedang mengajar, kunjungan antar kelas (seorang guru berkunjung ke kelas lain untuk berbagi pengalaman dalam pembelajaran) dan pertemuan individual (bertukar pikiran antara Kepala Madrasah dengan guru).

Kepala Madrasah lebih sering menggunakan teknik supervisi individual dengan cara memanggil guru yang kesulitan dalam menyusun kelengkapan administrasi pembelajaran. Teknik supervisi kelompok dalam bentuk: rapat kedinasan, diskusi kelompok, demonstrasi pembelajaran dan Workshop. Tindak lanjut merupakan kesinambungan dari kegiatan evaluasi. Hasil evaluasi menginformasikan pendidik yang memenuhi standar dan pendidik yang belum memenuhi standar.

Faktor pendukung Supervisi Akademik diuraikan sebagai berikut: adanya Jadwal Supervisi Akademik, Guru bersedia untuk dibina dan dibimbing oleh Kepala Madrasah maupun guru senior yang tergabung dalam Tim Pembantu Supervisi., Guru memiliki dokumen administrasi pembelajaran dengan baik, Kesanggupan guru senior membimbing teman sejawat. Peserta didik yang tertib, 


\section{Faizatun dan Fathul Mufid}

Kerjasama antar guru dan kualifikasi guru yang sesuai dengan standar. Hambatan Supervisi Akademik yang sangat umum terjadi di MAN 2 Pati, dijabarkan sebagai berikut: (a) Kurangnya persiapan guru saat disupervisi, (b) Jadwal supervisi berbenturan dengan kegiatan Kepala Madrasah. (c) kurang lengkapnya administrasi pembelajaran guru terutama Promes, Silabus, dan RPP. (d) Perbedaan latar belakang pendidikan, kondisi psikologi, keterampilan, kemampuan mengelola kelas dan pengalaman mengajar guru, (e) kurangnya pemahaman dan kesadaran pelaksanaan Supervisi Akademik. (f) Beban kerja yang terlalu berat dan kesibukan Kepala Madrasah.

Peran penting Kepala Madrasah dalam pelaksanaan supervise akademik adalah bagian dari penjaminan mutu pendidikan di madrasahnya. Tugas Kepala Madrasah berkewajiban melakukan pembinaaan pembimbingan dan pelatihan profesional terhadap guru agar terjadi peningkatan kompetensi profesional yang dimiliknya. Keterampilan Kepala Madrasah dalam mengelola dan memberdayakan guru berdampak pada kualitas pengembangan profesi guru dan mendesain kolaborasi serta kerjasama antar guru. Kepala Madrasah menguasai substansi perencanaan, pelaksanaan, penilaian proses pembelajaran dan penggunaan teknik Supervisi Akademik dengan baik akan berdampak positif terhadap kinerja guru sehingga proses pembelajaran lebih bermutu dan peningkatan mutu lulusan.

Dasar pelaksanaan supervisi akademik di dua madrasah tersebut mengacu pada Keputusan Direktur enderal PendidikanIslamNomor 6990 Tahun 2019 tentang Petunjuk Supervisi Pembelajaran di Madrasah Sasaran utama supervisi di MAN 1 Pati adalah seluruh guru mapel yang mengajar di MAN 1 Pati. Bagi guru pemula lebih diutamakan untuk dilakukan Supervisi Akademik. Kegiatan ini diatur dalam Keputusan Direktur Jendral Pendidikan Islam Nomor: 5792 Tahun 2019 tentang Petunjuk Teknis Program Induksi Guru Pemula Madrasah. Dengan difokuskannya sasaran Supervisi Akademik, diharapkan guru pemula memiliki kompetensi professional. 


\section{Faizatun dan Fathul Mufid}

Supervisi mempunyai peran mengoptimalkan tanggung jawab dari semua program. Dengan mengetahui kondisi aspek-aspek yang berkaitan dengan pendidikan secara rinci dan akurat, dapat diketahui dengan tepat pula apa yang diperlukan untuk meningkatkan kualitas pendidikan. Kegiatan supervisi idealnya melihat hal-hal negatif untuk diupayakan menjadi positif dan melihat mana yang positif untuk dapat ditingkatkan menjadi lebih baik lagi. pelaksanaannya bukan mencari-mencari kesalahan tetapi lebih terfokus pada unsur pembinaan, agar kondisi pekerjaan yang sedang disupervisi dapat diketahui kekurangannya (bukan semata-mata kesalahannya) untuk dapat diberitahu bagian yang perlu diperbaiki.

Menurut Roger A. Kauffman yang dikutip Nanang Fattah, perencanaan adalah proses penentuan tujuan atau sasaran yang hendak dicapai dan menetapkan jalan dan sumber yang diperlukan untuk mencapai tujuan seefisien dan seefektif mungkin (Fattah, 2010). Perencanaan merupakan tindakan menetapkan terlebih dahulu apa yang akan dikerjakan, bagaimana mengerjakannya, apa yang harus dikerjakan dan siapa yang mengerjakan. Oleh karena itu, perencanaan membutuhkan data dan informasi agar keputusan yang diambil tidak lepas kaitannya dengan masalah yang dihadapi pada masa yang akan datang.

Berpijak pada temuan-temuan penelitian di atas, diperkuat dengan pendapat Nanang, perencanaan adalah proses penentuan tujuan atau sasaran yang hendak dicapai dan menetapkan cara dan sumber yang diperlukan untuk mencapai tujuan tersebut seefisien dan seefektif mungkin. Perencanaan merupakan tindakan menetapkan terlebih dahulu apa yang akan dikerjakan, bagaimana mengerjakannya, apa yang harus dikerjakan dan siapa yang mengerjakannya. Oleh karena itu, perencanaan membutuhkan data dan informasi agar keputusan yang diambil tidak lepas kaitannya dengan masalah yang dihadapi pada masa yang akan datang.( Nanang;2008) Merunjuk pada konsep ini, penyusunan program Supervisi Akademik yang dibuat Kepala MAN Pati, telah dilakukan sesuai dengan prosedur. Penyusunan perencanaan program kegiatan Supervisi Akademik sekurangkurangnya telah menggambarkan apa yang telah dilakukan, cara melakukan, waktu 


\section{Faizatun dan Fathul Mufid}

pelaksanaan, fasilitas yang dibutuhkan, dan cara mengukur keberhasilan, namun belum terdokumentasi secara optimal.

Selaras dengan teori tersebut di atas, penyusunan perencanaan supervisi akademik di MAN Pati dilakukan oleh kepala madrasah dan wakilnya, beberapa guru senior yang ditunjuk dan dilegalkan dengan pemberian surat keputusan kepala madrasah. Penyusunan perencanaan tersebut disusun pada awal tahun pelajaran dan mengacu pada pencapaian $8 \mathrm{SNP}$, terdiri dari : program tahunan dan program semester, memuat penilaian, pembinaan, pemantauan serta dilengkapi dengan jaduwal dan instrumen yang akan digunakan dalam pelaksanaan supervisi akademik. Dengan instrumen kepala madrasah dapat mengetahui kompetensi guru, aspek-aspek pada pelaksanaan pembelajaran yang perlu dibantu, dibina serta ditingkatkan baik pada semester ganjil maupun genap dengan tujuan memperbaiki proses dan hasil belajar sehingga terjadi perubahan perilaku mengajar guru ke arah yang lebih baik.

Pada penelitian terdahulu yang dilakukan oleh Pawiro Ujarwanto, "Supervisi Akademik Kepala Sekolah dalam Meningkatkan Kinerja Guru Pendidikan Agama Islam (Studi Multikasus di MI Hidayatul Muttaqin Blayu dan SD Negeri Sukoanyar 1 Wajak)" (Ujarwanto, 2017) menunjukkan hasil meningkatnya kinerja guru setelah dilaksanakan supervisi akademik secara terjadwal oleh kepala sekolah/madrasah di MI Hidayatul Muttaqin Blayu dan SD Negeri Sukoanyar 1 Wajak. Hasil dari penelitian terdahulu memiliki kesamaan dengan hasil penelitian yang peneliti lakukan, yakni menyusun perencanaan supervisi akademik yang dilakukan di awal tahun pelajaran. Penyusunan perencanaan tersebut meliputi : program tahunan dijabarkan dalam program semester dan membuat jadwal pelaksanaan supervisi kunjungan kelas.

Keberhasilan pelaksanaan supervisi akademik yang dilakukan kepala madrasah sangat tergantung pada pemilihan dan penggunakan strategi yang tepat sasaran. Untuk merealisasikan keberhasilan tersebut tentu ada hambatan dan tantangan baik internal maupun eksternal. Salah satu hambatan internal ada pada 


\section{Faizatun dan Fathul Mufid}

guru itu sendiri. Berkenaan dengan hal tersebut, Glikman membagi tipologi guru menjadi empat yaitu : (a) guru memiliki abstraksi tinggi dan komitmen tinggi, (b) ada guru yang memiliki komitmen tinggi, abstraksi rendah, (c) ada guru yang memiliki komitmen rendah tetapi abstraksi tinggi, dan (d) guru yang memiliki abstraksi rendah dan komitmen rendah (Glickman, 2009).

Menghadapi tipe guru yang mempunyai abstraksi tinggi dan komitmen tinggi dibutuhkan strategi yang digunakan berbeda untuk menghadapi seorang guru yang mempunyai abstraksi tinggi tetapi komitmennya rendah. Oleh karena itu kepala madrasah sebagai supervisor dituntut peka dan paham dengan karakteristik guru yang dihadapi sehingga pemilihan strateginya akan tepat. Hal ini merupakan tuntutan pemerintah terhadap kepala madrasah sebagaimana tertuang pada Permendiknas Nomor 13 Tahun 2007 tentang kompetensi kepala sekolah yang kedua yaitu melaksanakan supervisi akademik terhadap guru dengan menggunakan pendekatan dan teknik yang tepat (depdiknas, 2007).

Sejalan dengan teori di atas, strategi pelaksanaan supervisi akademik yang dilakukan oleh kepala MAN Pati agar berjalan lancar, maka kepala madrasah perlu memahami karakteristik gurunya dan kemampuan guru yang beragam, sehingga dalam melaksanakan supervisi akademik mampu memilih dan menggunakan strategi dengan tepat guna meningkatkan kompetensi profesional guru yang dibinanya. Dengan adanya kesibukan pekerjaaan, kepala madrasah mendelegasikan kepada tiem pelaksana kegiatan supervise akademik langsung melalui kunjungan kelas. Hal ini diharapkan ada suasana yang berbeda pada guru yang didampingi di kelas daripada disupervisi oleh kepala madrasah sendiri, sehingga guru lebih terbuka berkomunikasi tentang beberapa kesulitan yang dihadapinya.

Teknik-teknik Supervisi Akademik yang digunakan kepala MAN Pati adalah teknik yaitu: (1) Teknik supervisi individual, dengan cara: kunjungan kelas, observasi kelas, pertemuan individual, dan kunjungan antar kelas (2) teknik supervisi kelompok dengan cara: diskusi kelompok, rapat guru, pelatihan /workshop. Teknik supervise yang paling tepat dan sering digunakan kepala 


\section{Faizatun dan Fathul Mufid}

madrasah adalah teknik supervise individual melalui kunjungan kelas, observasi dan pertemuan individual. Dari kegiatan tersebut diketahui secara langsung kelebihan dan kekurangan masing-masing guru secara obyektif sehingga mempermudah pemberian layanan perbaikan dan tindak lanjut

Strategi berikutnya kepala madrasah mengadakan tindak lanjut hasil dari supervisi akademik agar memberikan dampak nyata untuk meningkatkan kompetensi profesional guru. Tindak lanjut tersebut berupa penguatan dan penghargaan diberikan kepada guru yang telah memenuhi standart, teguran yang bersifat mendidik diberikan kepada guru yang belum memenuhi standar, dan guru diberi kesempatan untuk mengikuti peltihan, seminar, workshop atau diklat lebih lanjut. Temuan ini relevan dengan tuntutan pemerintah terhadap Kepala Madrasah sebagaimana tertuang dalam Permendiknas Nomor 13 Tahun 2007 tentang Kompetensi Kepala Sekolah, poin kedua yaitu : melaksanakan Supervisi Akademik terhadap guru dengan menggunakan pendekatan dan teknik yang tepat.

Pada penelitian terdahulu yang dilakukan oleh Mudaki, yang berjudul "Implementasi Supervisi Akademik Kepala Sekolah Dalam Meningkatkan Profesionalisme Guru (Studi Multikasus di MAN Sampang dan SMA Negeri 1 Kecamatan Sampang, Kabupaten Sampang)", menunjukkan hasil meningkatnya kompetensi profesional guru setelah dilaksanakan supervisi akademik secara terjadwal oleh kepala sekolah/madrasah di MAN Sampang dan SMA Negeri 1 Kecamatan Sampang, Kabupaten Sampang (Mudaki, 2015). Hasil dari penelitian terdahulu memiliki kesamaan dengan hasil penelitian yang peneliti lakukan, yakni strategi pelaksanaan supervisi akademik dengan mendelegasikan kewenangan supervisi akademik kepada wakil kepala madrasah, dan guru-guru senior. Sasaran pelaksanaan supervisi akademik adalah kemampuan guru dalam merencanakan kegiatan pembelajaran, melaksanakan kegiatan pembelajaran, menilai hasil pembelajaran, memanfaatkan hasil penilaian untuk peningkatan layanan pembelajaran, menciptakan pembelajaran yang menyenangkan, memanfaatkan hasil penilaian untuk peningkatan layanan pembelajaran, menciptakan pembelajaran 


\section{Faizatun dan Fathul Mufid}

yang menyenangkan, memanfaatkan sumber belajar yang tersedia di lingkungan sekitar, dan mengembangkan interaksi pembelajaran dengan menggunakan strategi, metode dan teknik yang tepat.

Menurut TR Morrison yang dikutip Nanang ada tiga faktor penting dalam konsep evaluasi, yaitu : pertimbangan (judgement), deskripsi objek penilaian, dan kriteria yang tertanggung jawab (defensible criteria) (Fattah, 2010). Ada tiga kegiatan yang dilakukan supervisor dalam aktivitas mengevaluasi yaitu : identifikasi tujuan evaluasi, penyusunan desain dan metodologi evaluasi serta pengukuran. Suharsimi Arikunto mengidentikkan kegiatan evaluasi program yang dilaksanakan supervisor dengan kajian penelitian. Proses evaluasi merupakan upaya mencari suatu fakta dan kebenaran, oleh karena itu dalam pelaksanaan harus objektif dan rasional, prinsip metode ilmiah harus diterapkan. Ada beberapa teknik evaluasi program yang dipakai oleh supervisor dalam mencari data untuk tindak lanjut, yaitu : (a) test, (b) observasi, (c) laporan diri, (d) evaluasi diri, dan (e) teman sejawat (Suharsimi, 2009).

Sejalan dengan teori di atas, kegiatan evaluasi supervisi akademik di MAN Pati dilakukan dalam suatu siklus secara periodik dan sistematis, dalam pelaksanakan evaluasi menggunakan instrumen baku yang ditetapkan oleh Kementerian Agama. Kepala madrasah melakukan pengawasan, pembinaan, pemantauan, penilaian dan analisis hasil supervisi dalam satu semester. Supervise dan Evaluasi dilakukan dua kali dalam setahun, yaitu diakhir semester ganjil dan semester genap melalui tahapan pembahasan hasil supervisi administrasi pembelajaran, pelaksanaan pembelajaran dan penilaian hasil belajar, dilanjutkan dengan analisis hasil pelaksanaan supervisi kunjungan kelas, yang pelaksanaannya dibantu oleh tiem pelaksana supervise akademik ( wakabid akademik dan guru senior/guru inti)yang dilagalkan dengan surat keputusan kepala madrasah.

Beberapa rangkaian kegiatan evaluasi atau penilaian yang dilakukan Kepala Madrasah terhadap program pembelajaran yang dibuat oleh guru diantaranya adalah: (1) pemetaan KI dan KD, (2) program tahunan, (3) program semester, (4) 


\section{Faizatun dan Fathul Mufid}

silabus (5) jaduwal tatap muka, (6) RPP (7) KKM, (8) Agenda harian guru, (9) Buku nilai, (10) Kisi-Kisi Soal, (11) analisis nilai, (12) program perbaikan dan pengayaan, dan (13) buku sumber yang digunakan guru sebagai sumber materi. Evaluasi terhadap performa mengajar guru juga dilakukan melalui kunjungan kelas, menilai rangkaian kegiatan selama proses pembelajaran berlangsung. Mulai dari kegiatan membuka pelajaran, kegiatan inti yang di dalamnya mengarah pada pendekatan, metode dan strategi pembelajaran yang mampu membekali peserta didik memiliki kecakapan abad 21-yang mencakup: 4C (Communication, Collaboration, Critical Thinking and Problem Solving, Creative and Innovative).

Hasil temuan penelitian ini mengungkapkan bahwa khusus penilaian supervisi teknik individual yaitu supervisi kunjungan kelas, dinilai pada saat kegiatan supervise berakhir, yaitu pada waktu istirahat. Kepala Madrasah menyeleksi permasalahan dan kesulitan yang dialami guru selama pembelajaran di kelas serta menentukan skala prioritas permasalahan yang perlu mendapatkan penanganan segera. Sebagai tindak lanjut penilaian supervisi akademik, Kepala Madrasah menyampaikan hasil penilaian melalui pertemuan individual dengan guru yang disupervisi dalam bentuk supervisi klinis yaitu pertemuan pribadi untuk melakukan diskusi. Dalam diskusi guru diberi kesempatan untuk mengungkapkan pendapatnya mengenai proses pembelajaran yang sudah dilaksanakan. Kepala Madrasah menunjukkan hasil observasi, guru mencermati dan menganalis hasil observasi. Kepala Madrasah menyampaikan kekurangan dan kelebihan guru dalam pembelajaran dengan dilandasi sikap terbuka, suasana akrab dan kondusif. Hasil akhir dari supervisi akademik ini adalah rencana guru sendiri (teacher self-plan).

Pada penelitian terdahulu yang dilakukan oleh Tabi' in, berjudul 'Supervisi Akademik Dalam Upaya Peningkatan Profesionalisme Guru PAI Madrasah di KKMI Kecamatan Penjaringan Jakarta Utara”, menunjukkan hasil meningkatnya profesionalisme guru setelah dilaksanakan supervisi akademik secara terjadwal oleh pengawas (Tabi'in, 2017). Hasil dari penelitian terdahulu memiliki kesamaan 


\section{Faizatun dan Fathul Mufid}

dengan hasil penelitian yang peneliti lakukan, yakni evaluasi supervisi kunjungan kelas dilaksanakan setelah berakhirnya kegiatan supervisi yaitu waktu istirahat

Tindak lanjut juga dilakukan oleh Kepala Madrasah berupa: penguatan dan penghargaan diberikan kepada guru yang berkompeten, memiliki kinerja yang bagus dibuktikan dengan hasil penilaian melampuai batas nilai yang telah distandarkan oleh Kementerian Agama dengan mengikut sertakan dalam berbagai kegiatan lomba guru berprestasi dan promosi dalam jabatan yang ada di madrasah dan kepla madrasah. Teguran yang bersifat edukatif diberikan kepada guru yang belum memenuhi standar dan guru tersebut diberi kesempatan untuk mengikuti pelatihan/penataran lebih lanjut baikdalam forum MGMP maupun seminar dan atau worshoop. Tindak lanjut bagi guru yang belum melengkapi perangkat pembelajaran dengan memberikan teguran lisan, dan toleransi berupa tenggang waktu tertentu untuk melengkapi perangkat yang kurang serta memberikan pemahaman akan pentingnya program pembelajaran bagi seorang guru ketika mengajar.

Berdasarkan pada temuan penelitian terkait kegiatan Supervisi Akademik oleh Kepala MAN 1 Pati dan MAN 2 Pati, pelaksanaannya sesuai dengan Keputusan Direktur Jenderal Pendidikan Islam Nomor 6990 Tahun 2019 tentang Petunjuk Teknis Supervisi Pembelajaran di Madrasah. Peraturan ini menjelaskan pelaksanaan Supervisi Akademik diselenggarakan secara sistematis dengan tujuan yang jelas dan terencana. Kegiatan Supervisi Akademik mencakup : perencanaan, persiapan, pelaksanaan, pelaporan, dan tindak lanjut hasil supervisi”' (Depdiknas, 2005).

\section{Faktor-faktor pendukung dan penghambat}

Keberhasilan pelaksanaan supervisi kepala sekolah dipengaruhi oleh beberapa faktor pendukungnya, yakni guru yang menjadi sasaran supervisi bersikap koperatif dan terbuka terhadap proses supervisi yang dilakukan oleh kepala sekolah (Suradi, 2018). 


\section{Faizatun dan Fathul Mufid}

Selaras dengan teori tersebut di atas, guru menunjukkan bahwa hal yang paling mendukung kepala sekolah dalam melaksanakan supervisi adalah kesiapan guru yang akan disupervisi. Adanya jaduwal supervisi akademik yang memungkinkan guru melakukan persiapan dan penyusunan perangkat pembelajran, Kepala Madrasah melaksanakan supervisi secara berkesinambungan, Berprofesi yang sama sebagai guru. Selain melakukan pembinaan secara langsung, kepala sekolah juga mengirim sejumlah guru untuk mengikuti pelatihan baik pelatihan ditingkat kabupaten, propinsi, bahkan ditingkat nasional. Faktor penghambatnya adalah : (a) motivasi guru rendah sehingga Guru merasa terbebani dengan pelaksanaan supervise, (b) pemahaman kepala sekolah dan guru tentang supervisi akademik belum sempurna, (c) perbedaan latar belakang peendidikan guru dengan supervaisor dan (d) rendahnya pengembangan kualitas diri guru

Pada penelitian terdahulu yang dilakukan oleh Suradi, berjudul "Supervisi Akademik Kepala Sekolah terhadap Kinerja Guru Pendidikan Agama Islam di Sekolah Dasar Negeri 79 Kota Bengkulu" menunjukkan hasil meningkatnya kinerja guru setelah dilaksanakan supervisi akademik secara terjadwal oleh kepala sekolah di Sekolah Dasar Negeri 79 Kota Bengkulu (Suradi, 2018). Hasil dari penelitian terdahulu memiliki kesamaan dengan hasil penelitian yang peneliti lakukan, yakni dampak penunjang dilaksanakan supervisi akademik adalah kesiapan guru untuk disupervisi dengan bersikap kooperatif, sedangkan faktor penghambatnya adalah motivasi guru yang rendah, guru tidak siap disupervisi, kesibukan kepala madrasah, kurangnya sarana dan prasarana, dan rendahnya pengembangan kualitas diri guru.

\section{Peran Kepala Madrasah sebagai supervisor}

Pelaksanaan supervisi akademik yang dilakukan oleh kepala madrasah memiliki peran penting terhadap peningkatan kompetensi professional guru. Berdasarkan temuan penelitian diketahui peran Kepala MAN 1 Pati dan MAN 2 Pati sebagai Supervisor, memiliki 3 (tiga) kompetensi, yaitu: Kompetensi merencanakan program supervisi akademik dalam rangka meningkatkan kompetensi professional guru, Kompetensi melaksanakan supervisi akademik 


\section{Faizatun dan Fathul Mufid}

terhadap guru dengan menggunakan pendekatan dan teknik supervisi yang tepat, Kompetensi untuk menindaklanjuti hasil supervisi akademik terhadap guru dalam rangka meningkatan kompetensi professional guru. Kepala sekolah harus memberikan layanan yang optimal kepada seluruh pelaksanan Pendidikan hususnya pelayanan bagi guru yang secara professional bertanggungjawab langsung terhadap proses pembelajran di sekolah.

Hal tersebut selaras dengan ketentuan yang dijelaskan dalam permendiknas no. 13 tahun 2007 bahwa kepala sekolah sebagai supervaisor harus mampu memiliki kompetensi dinataranya, pertama merencanakan program supervisi akademik dalam rangka meningkatkan kompetensi professional guru, kedua melaksanakan supervisi akademik terhadap guru dengan menggunakan pendekatan dan teknik supervisi yang tepat, ketiga menindaklanjuti hasil supervisi akademik terhadap guru dalam rangka meningkatan kompetensi professional guru.

Kepala Madrasah mempunyai peran sangat strategis dalam mengelola pendidikan dan meningkatkan mutu pendidikan yang berkualitas. Salah satu peran Kepala Madrasah dalam menjalankan tugasnya adalah Supervisor, dimana kepala madrasah berkewajiban untuk membina guru-gurunya agar memiliki kompetensi profesional dalam mengajar. Tugas Kepala Madrasah menciptakan iklim yang memungkinkan guru untuk melakukan proses pembelajaran yang bermutu menumbuh kembangkan kreativitas, daya inovatif, kemampuan pemecahan masalah, berfikir kritis, kretif dan memiliki naluri jiwa kewirausahaan bagi peserta didik sebagai produk dari sistem pendidikan. Oleh karena itu, Kepala Madrasah harus memiliki kompetensi supervisi akademik sebaimana yang telah tertuang dalam PMA nomor 58 tahun 2018 adalah kompetensi supervise akademik, yang intinya kemampuan membina guru dalam meningkatkan mutu proses pembelajaran. Sasaran supervise akademik adalah semua guru terutama guru pemula yang belum memenuhi standar, artinya guru kesulitan dalam : (1) merencanakan kegiatan pembelajaran, meliputi : penyusunan Silabus, dan RPP, (2) melaksanakan proses pembelajaran yang mendidik dan dialogis, meliputi : (a) penguasaan materi pokok, 


\section{Faizatun dan Fathul Mufid}

(b) pemilihan strategi/metode/teknik pembelajaran, dan (c) penggunaan media dan TIK dalam pembelajaran, (3) mengevaluasi pembelajaran meliputi : nilai proses dan hasil pembelajaran, dan (4) Penelitian Tindakan Kelas.

Dalam menyusun perencanaan program Supervisi Akademik, baik di MAN 1 Pati maupun MAN 2 Pati, melibatkan seluruh elemen madrasah meliputi : Wakil kepala dan guru senior yang diberitugas sebagai Tim Pembantu Supervisi. Program disosialisasikan ke seluruh guru melalui rapat dinas dewan guru. Di dalam rapat tersebut guru diberikan kesempatan untuk memberikan masukan, pendapat dan koreksi berhubungan dengan jadwal pelaksanaan supervisi yang telah disusun bersama Tim Pembantu Supervisi. Berpijak pada temuan-temuan data penelitian yang dilakukan peneliti di dua lokasi yaitu: MAN 1 Pati dan MAN 2 Pati, pada lintas kasus disimpulkan bahwa: Adanya persamaan pelaksanaan kegiatan Supervisi Akademik di MAN 1 Pati dan MAN 2 Pati. Hasil penelitian menunjukkan tidak adanya perbedaan (Lintas Kasus) pada kedua madrasah tersebut. Hal ini disebabkan karena adanya kepemimpinan yang sama. Kepala Madrasah yang baru di MAN 2 Pati, kegiatan Supervisi Akademik melanjutkan program yang telah disusun oleh Kepala Madrasah yang lama (Kepala MAN 1 Pati), yang sebelumnya ditugaskan menjadi kepala pelaksana tugas di MAN 2 Pati, sampai terisinya jabatan Kepala Madrasah di MAN 2 Pati. Oleh karena itu kegiatan Supervisi Akademik melanjutkan program yang telah disusun oleh Kepala Madrasah yang lama, yang sekarang ini tetap menjabat sebagai Kepala Madrasah di MAN 1 Pati

\section{Simpulan}

Perencanaan program Supervisi Akademik di MAN 1 Pati dan MAN 2 Pati, disusun setiap awal tahun pelajaran dengan menggunakan model kolaboratif, berupa dokumen Program Supervise Akademik meliputi Program Tahunan dan Program Semester, dilengkapi dengan (1) Instrumen Supervisi RPP, (2) Instrumen Supervisi Proses Pembelajaran (K13), dan (3) Instrumen Supervisi Penilaian Proses dan Hasil Belajar. (4) jaduwal pelaksanaan supervise akademik. Pelaksanakan Supervisi Akademik berpedoman pada Keputusan Dirjen Pendis No. 6690 tahun 


\section{Faizatun dan Fathul Mufid}

2019 tentang Petunjuk Teknis supervisi Pembelajaran di Madrasah, dan Keputusan Dirjen Pendis No. 5792 Tahun 2019 tentang Petunjuk Teknis Program Induksi Guru Pemula di Madrasah, dimana sasaran supervise adalah semua guru terutama guru pemula. Prinsip yang digunakan dalam pelaksanaan supervise adalah menciptakan hubungan kemanusiaan yang harmonis, demokratis, berkesinambungan, integral dengan program pendidikan, komprehensif, konstruktif, obyektif, dan ilmiah. Strategi pelaksanaan supervisiak akademik menggunakan dua Teknik yaitu (1) teknik individual, dengan cara: kunjungan kelas, observasi kelas, kunjungan antar kelas dan pertemuan individual; (2) Teknik Kelompok, dengan cara: rapat guru, diskusi, demonstrasi pembelajaran dan Workshop.

Hasil pelaksanaan supervise dianalisis dan dievaluasi bersama-sama dengan tim guru, dan membuat catatan hasil supervisi yang didokumentasikan sebagai laporan. Hasil evaluasi digunakan untuk memperbaiki program Supervisi pada tahun berikutnya. Kepala Madrasah menindaklanjuti kesulitan yang dihadapi guru, menemukan pendekatan yang tepat terhadap masing-masing guru dengan karakter dan kemampuan yang beragam. Tindak lanjut berupa: (a) penguatan dan penghargaan diberikan kepada yang telah memenuhi standar, dan (b) Teguran yang bersifat mendidik diberikan kepada guru yang belum memenuhi standar dan pembinaan lanjutan dengan pemberian kesempatan untuk mengikuti pelatihan/penataran / workshop

Faktor pendukung keberhasilan SupervisiAkademik di MAN 1 Pati dan MAN 2 Pati, yaitu : (1) kesediaan guru untuk disupervisi, (2) adanya jadwal Supervisi Akademik; (3) terciptanya hubungan humanis antar guru, (4) Berprofesi yang sama, (5) Guru senior kooperatif, (6) Administrasi mengajar lengkap dan dikerjakan dengan baik, (7) Kepala Madrasah melaksanakan supervisi secara berkesinambungan pada semua guru, (8) Kondisi peserta didik yang tertib (9) kerja sama yang solid antar guru. sedangkan Faktor penghambat dilaksanakan Supervisi Akademik diantaranya : (1) adanya Guru yang belum siap untuk disupervisi, (2) 
Kesibukan Kepala Madrasah dan guru, (3) Kesulitan Kepala Madrasah membimbing guru yang memiliki latar belakang pendidikan yang berbeda, dan (4) rendahnya kesadaran akan Pengetahuan dan pemahaman pentingnya Supervisi Akademik (5) kurangnya ketrampilan sebagian guru dalam pemanfaatan ICT ( Information and Communication Technoligi).

Kepala Madrasah mempunyai beberapa peran dalam menjalankan tugasnya, adalah dimensi kompetensi supervisi, me;iputi (1) merencanakan programSupervisi Akademikdalam rangka peningkatan kompetensi professional iguru, (2) melaksanakan Supervisi Akademik terhadap guru dengan menggunakan pendekatan dan tekniksupervisi yang tepat, dan (3) menindaklanjuti hasil Supervisi Akademik terhadap guru dalam rangka peningkatan kompetensi profesional guru.

\section{DAFTAR PUSTAKA}

Departemen Pendidikan dan Kebudayaan Republik Indonesia, Kamus Besar Bahasa Indonesia, (Jakarta, Perum Balai Pustaka, 1988), 420, 796

Departemen Pendidikan dan Kebudayaan Republik Indonesia. Kamus Besar bahasa Indonesia. Jakarta, Perum Balai Pustaka, 1988.

Departemen Pendidikan Nasional (Depdiknas), “19 Tahun 2005, Peraturan Pemerintah, Standar Nasional Pendidikan”. (16 Mei 2005).

Glickman, C.D., Gordon, S.P., and Ross-Gordon, J.M. Supervision and Instructional Leadership A Development Approach, Seventh Edition. Boston: Perason, 2007.

Kemenag, 58 Tahun 2017, Peraturan Menteri Agama Republik Indonesia, Kepala Madrasah, (16 November 2017)

Kemenag, Nomor 6690 Tahun 2019, Keputusan Direktur Jenderal Pendidikan Islam, Petunjuk Teknis Supervisi Pembelajaran di Madrasah, (9 Desember 2019)

Masaong, Abd. Kadim. Supervisi Pembelajaran dan Pengembangan Kapasitas Guru. Bandung : Alfabeta, 2012.

Maunah, Binti. Supervisi Pendidikan Islam :Teori dan Praktik. Yogyakarta : Teras, 2009.

Sa'ud Udin Syaefudin dan Syamsudin Makmum Abid. Perencanaan Pendidikan Suatu Pendekatan Komprehensif. Bandung : PT. Remaja Rosdakarya, 2009.

Salim, Peter dan Salim, Yenny. Kamus Bahasa Indonesia Kontemporer. Jakarta: Modern English Press, 1993. 
Sudjana, Nana, dkk., Standar Mutu Pengawas. Jakarta: Departemen Pendidikan Nasional, 2006.

Sugiyono. Metode Penelitian Kuantitatif Kualitatif dan R\&D. Bandung: Alfabeta, 2013.

Tim Penyusun Kamus Pusat Pembinaan dan Pengembangan Bahasa. Kamus Besar Bahasa Indonesia. Jakarta : Balai Pustaka, 2009.

Ushani, Desak Ketut Dina; Indikator Guru Inspiratif dan Profesional, diakses pada 12 Februari 2020, : https://www.researchgate.net/publication/315328968 .

Yunandra, Standar Kompetensi Kepala Sekolah/Madrasah, 18 September 2019, https://yunandra.com/standar-kompetensi-kepala-sekolah-madrasah/

Zafi, Ashif Az, "Supervisi Akademik Pengawas Pendidikan Agama Islam di SMA Negeri 1 dan SMA Negeri 7 Purworejo". Thesis. UIN Sunan Kalijaga Yogyakarta. 2016. 
Faizatun dan Fathul Mufid 